\title{
HUMOR POLITIZADO: O USO DAS ILUSTRAÇÕES SATÍRICAS NA IMPRENSA PARAIBANA NOS ANOS 70
}

\author{
Rosildo Raimundo Brito ${ }^{1}$
}

\begin{abstract}
Resumo: Este trabalho apresenta um breve registro sobre o uso político e ideológico das ilustrações satíricas durante a década de 1970. Trata-se de uma abordagem que busca, dentro da perspectiva histórica, apresentar um panorama acerca do período mais efervescente da produção satírico-humorística da imprensa paraibana, destacando o trabalho combativo dos principais humoristas gráficos paraibanos em atuação na época. Neste contexto, este ensaio objetiva contribuir com os estudos acerca do desenvolvimento do humor gráfico enquanto uma das manifestações político-ideológicas mais provocativas e criativas atreladas ao universo jornalístico, em cujo seio os desenhos satíricos ganham contornos sociais, políticos e culturais, de grande valor histórico. Para além dos resultados obtidos e que apontam para as idiossincrasias pertinentes à produção gráfico-narrativa pertinente ao período analisado, este trabalho também contribuir para um maior alargamento dos trabalhos no campo da História Cultural em que a imagem iconográfica tem se tornando um objeto de estudo cada vez mais explorado pelos historiadores, enquanto valiosa fonte de pesquisa.
\end{abstract}

Palavras-chave: Humor gráfico; Ilustrações satíricas; História Cultural; Imprensa paraibana.

\section{HUMOR POLITIZED: THE USE OF SATIRICAL ILLUSTRATIONS IN THE PARAIBANA PRESS IN THE 70s}

\begin{abstract}
This paper presents a brief record on the political and ideological use of satirical illustrations during the 1970s. It is an approach that seeks, within the historical perspective, to present a panorama about the most effervescent period of the satirical-humoristic production of the press Paraíba, highlighting the combative work of the main graphic comedians from Paraíba at the time. In this context, this essay aims to contribute to the studies about the development of graphic humor as one of the most provocative and creative politicalideological manifestations linked to the journalistic universe, in which the satirical drawings gain social, political and cultural contours, of great historical value. In addition to the results obtained and which point to the idiosyncrasies pertinent to the graphic-narrative production pertinent to the analyzed period, this work also contribute to a broader extension of the works in the field of Cultural History in which the iconographic image has become an object of study each once again explored by historians, as a valuable source of research.
\end{abstract}

Keywords: Graphic humor; Satirical illustrations; Cultural History; Paraibana Press.

\section{HUMOR POLITIZADO: EL USO DE LAS ILUSTRACIONES SATÍRICAS EN LA PRENSA PARAIBANA EN LOS AÑOS 70}

Resumen: Este trabajo presenta un breve registro sobre el uso político e ideológico de las ilustraciones satíricas durante la década de 1970. Se trata de un enfoque que busca, dentro de

\footnotetext{
${ }^{1}$ Doutorando em História Social pela Universidade de São Paulo (USP). Professor Adjunto da Universidade Federal de Campina Grande (UFCG), lotado na Unidade Acadêmica de Arte e Mídia.
} 
la perspectiva histórica, presentar un panorama sobre el período más efervescente de la producción satírico-humorística de la prensa paraibana, destacando el trabajo combativo de los principales humoristas gráficos paraibanos en actuación en la época. En este contexto, este ensayo objetiva contribuir con los estudios acerca del desarrollo del humor gráfico como una de las manifestaciones político-ideológicas más provocativas y creativas vinculadas al universo periodístico, en cuyo seno los dibujos satíricos ganan contornos sociales, políticos y culturales, de gran valor histórico. Además de los resultados obtenidos y que apuntan a las idiosincrasias pertinentes a la producción gráfica-narrativa pertinente al período analizado, este trabajo también contribuye a una mayor ampliación de los trabajos en el campo de la Historia Cultural en que la imagen iconográfica se ha convertido en un objeto de estudio cada vez más explotada por los historiadores, como valiosa fuente de investigación.

Palabras clave: Humor gráfico; Ilustraciones satíricas; Historia Cultural; Prensa paraibana.

\section{INTRODUÇÃO}

Fundamentados nas bases epistemológicas inovadoras da Nova História, sobretudo, no que diz respeito à noção de ampliação dos documentos históricos herdados desta, os estudos no campo da História Cultural tem avançado nas abordagens contemplando os diversos tipos de imagens em uso na sociedade por séculos. E, de modo particular, aqueles advindos do desafiante universo iconográfico cuja legitimação enquanto objeto de valor histórico atravessou um longo e conturbado percurso ${ }^{2}$. Apesar de o interesse da historiografia pela imagem vir ocorrendo desde os primeiros trabalhos da História da Arte, no século XIX, como aponta Meneses (2003), a discussão sobre a apropriação da iconografia no campo de estudos da História, enquanto documento histórico, é uma abordagem relativamente recente e que convida os historiadores para uma reflexão mais profunda acerca do potencial cognitivo e testemunhal do documento visual.

E no abrir deste novo horizonte do qual a iconografia representa um vasto caminho a ser trilhado pelos pesquisadores, está a caricatura que, conforme enfatiza o historiador Gawryszewsky (2008), apesar de ter se tornado um termo usual e alvo de estudos de diversos campos do saber, ainda permanece sendo uma valiosa fonte documental a espera de estudos ainda mais amplos. É, portanto, dentro deste cenário que este trabalho se situa, apresentando uma abordagem com finalidades historiográficas sobre o uso das ilustrações satíricohumorísticas presentes na imprensa paraibana durante os anos 1970. Antes disto, porém, embora não seja este o foco principal do artigo, vamos apresentar uma breve abordagem

\footnotetext{
2 Para mais a respeito da problemática envolvendo a legitimação da iconografia no campo da História, ver Vovelle (1997).
} 
acerca da função política e ideológica desempenhada pela caricatura através de seus diversos gêneros humorísticos, dentre os quais, como se verá, a charge e as histórias em quadrinhos ocupam um lugar de destaque.

\section{A FUNÇÃO POLÍTICO-IDEOLÓGICA DA CARICATURA}

Considerada o campo privilegiado das ilustrações satírico-humorísticas, a caricatura ${ }^{3}$ prossegue despertando o interesse de pesquisadores dos mais diversos campos de estudo. Trata-se, como defende Barbieri (2017), o lugar privilegiado da sátira política e social e de que se valem as mais diversas publicações ao retratarem a realidade social apelando para o cômico. E é a partir desse aspecto que uma grande quantidade de estudos foi desenvolvida no transcorrer das últimas décadas, com uma atenção voltada em grande parte, para a análise e compreensão dos diversos gêneros ilustrativos satírico-humorísticos em uso na imprensa, por meio dos quais é possível uma compreensão mais alargada não apenas dos costumes e práticas culturais de determinadas épocas, mas também do próprio modo de intervenção político e ideológico dos periódicos que compõem o universo jornalístico e que se utilizam desses gêneros como importantes recursos comunicacionais ${ }^{4}$.

Dentro deste contexto, a rica trajetória da caricatura e seus gêneros configurativos em uso nos jornais e revistas ao longo dos dois últimos séculos tem revelado a importância do desenho humorístico na imprensa, seja como documento histórico, como fonte de informação social e política, como termômetro de opinião, como expressão artística e literária ou como simples forma de diversão e passatempo (FONSECA, 1999, p. 13). Uma trajetória que tem início com o surgimento dos primeiros jornais na época da imprensa régia, e posteriormente com o surgimento da imprensa satírica, a partir do sucesso estrondoso das revistas ilustradas

\footnotetext{
${ }^{3}$ Para fins de definição teórico-conceitual, ressaltamos que o termo caricatura empregado neste trabalho está ancorado na noção genérica apresentada por autores diversos, a exemplo de Fonseca (1999). Riani (2002) e Melo (2003), os quais se referem à caricatura enquanto designação geral e abrangente para uma forma de arte que se expressa através do desenho, da pintura e de outras formas de arte. Nessa acepção geral do termo caricatura, conforme destaca Joaquim da Fonseca: "podemos entender como formas dela: a charge, o cartum, o desenho de humor, a tira cômica, a historia em quadrinhos de humor, o desenho animado e a caricatura propriamente dita, isto é, a caricatura pessoal (FONSECA, 1999, p. 17).

${ }^{4}$ Visto que não é pretensão deste trabalho aprofundar a discussão em torno da diversidade de gêneros que configuram a caricatura enquanto campo específico que dá nome às diversas expressões do humor gráfico, destaca-se como sugestão para esta finalidade, a leitura dos trabalhos dos pesquisadores Ramos (2009) e Gawryszewsky (2008), mencionados na referência bibliográfica.
} 
já a partir da segunda metade do século $\mathrm{XIX}^{5}$. Contudo, o crescimento da caricatura no mercado editorial avançou significativamente, se consolidando como recursos imagéticos de grande aceitação do público, a partir do século XX, como destaca Bahia (1980):

No começo do século XX, a caricatura já compõe o formato editorial obrigatório de jornais e revistas. [...] nesse mercado, em que a concorrência é ditada pela qualidade, caricaturistas, chargistas, ilustradores desempenham funções relevantes, que vão dos redatores artísticos aos repórteres gráficos. Assinam espaços valorizados nos diários e nas revistas, preferidos que são por leitores que privilegiam o humor, a opinião política ilustrada, o desenho que facilita a compreensão dos fatos (BAHIA, 1990, p. 124-125).

Não obstante, é preciso destacar que, para além dos avanços tecnológicos dos maquinários de impressão, o avanço da caricatura se deu devido ao talento e ao engajamento de um seleto grupo de artistas gráficos, de cujas mãos saíram os traços habilidosos que desenharam o futuro do humor gráfico no país. Dentre os nomes mais conhecidos estão os de Ângelo Agostini (1843 -1910), Henrique Fleiuss (1823-1882); J. Carlos (1884 - 1950), Luis Sá (1907-1979) e Carlos Estevão (1921 - 1972) . Foi através dos trabalhos destes e, sobretudo, dos dois primeiros que, conforme destaca Vergueiro (2017), se tornou evidente a precoce participação do humor gráfico na discussão da realidade política e social brasileira. Estes inspiraram uma série de gerações de desenhistas e ilustradores que, do mesmo modo, desempenharam funções diversas na arte da narrativa gráfica. Em sua grande maioria, esses artistas concentravam seus esforços em produções chargísticas voltadas para a crítica política ou de costumes e alguns deles tiveram uma produção seriada que poderia ser equiparada àquilo que hoje em dia é genericamente denominado de "historia em quadrinhos" (VERGUEIRO, 2017, p. 17).

\footnotetext{
${ }^{5}$ De acordo com Cavalcanti (2005), a primeira manifestação da caricatura impressa no Brasil, ocorreu em 25 de abril de 1831, no jornal pernambucano, O Carcundão. Em 1832, segundo este mesmo autor, também na cidade de Recife, aparecia outra publicação que contém humor gráfico na capa: O Carapuceiro e que trazia igualmente um caráter satírico, cujo redator era o monge beneditino Miguel do Sacramento Lopes Gama. Não obstante, para o pesquisador Hermam Lima, o periódico a apresentar a primeira caricatura foi o Jornal do Commercio, em dezembro de 1837. Trava-se de um desenho feito pelo ilustrador Manoel de Araújo Porto-Alegre, intitulada de A Campainha e o Cujo, apontado por este autor como a primeira charge publicada na imprensa brasileira. Seguido disto, veio o fenômeno editorial das revistas ilustradas detalhado em diversos trabalhos já publicados, dentre os quais os de Lima (1963); Fonseca (1999) e Magno (2012).

6 Destes, o mais renomado é o ítalo-brasileiro Ângelo Agostini, apontado como responsável pela série em linguagem gráfica sequencial (1843-1910) bastante similar às histórias em quadrinhos, o que o tornou precursor do meio, como defende Vergueiro (2017). Além de cartunista, caricaturista, ilustrador, ele também desempenhava a função de crítico, o que o impulsionou a envolver-se com questões políticas.
} 
Foi por meio do emprego desses dois gêneros específicos: a charge e os quadrinhos nos periódicos jornalísticos, sobretudo, nos jornais de circulação diária, que a caricatura conquistou o status de lugar privilegiado da sátira política e social ${ }^{7}$. Tratam-se aqui de dois dos mais significativos e instigantes gêneros gráfico-narrativos em torno dos quais vem se desenvolvendo vários estudos de forma interdisciplinar envolvendo a contribuição dos mais diversos campos de conhecimento das ciências humanas. Parte dos estudos se detém nos aspectos estéticos e conteudísticos que caracterizam e aproximam esses gêneros, muito em uso nos jornais espalhados em todo o país. E, para além das semelhanças de natureza gráficonarrativa, muitos autores chamam a atenção para o uso da sátira enquanto fio condutor da comicidade que caracterizam tanto a charge como as histórias em quadrinhos, especialmente, as tiras cômicas.

Ao estudar a linguagem dos quadrinhos, a pesquisadora Danielle Barbieri, por exemplo, destaca que, como filho das vinhetas satíricas, os quadrinhos fazem grande uso da caricatura desde os seus primórdios, até o ponto de haver criado em nossa cultura uma intensa identificação entre imagens caricaturescas e imagens de quadrinhos (BARBIERI, 2017, p. 24). E é esse aspecto em comum que aproxima a charge e os quadrinhos, o qual está atrelado, em grande parte, à habilidade caricatural dos desenhistas, que tem contribuído para a função política desempenhada por ambos no espaço jornalístico que, conforme ressalta Sodré (1999), sempre teve a política, como temática essencial. E este caráter político, por sua vez, vale salientar, encontra-se disseminado, não apenas através do conteúdo publicado na editoria de política ou em conteúdos diversos espalhados pelas demais, mas também e, por que não dizer, de sobremaneira, por meio da opinião que é trabalhada por todos os meios de comunicação.

De acordo com Luiz Amaral (2001), o jornalismo desempenha quatro funções: política, econômica, educativa e de entretenimento. Por função política, entendem-se os meios de informação, em sua ação crescente, como instrumento de direção dos negócios públicos, e como órgãos de expressão e de controle de opinião pública (AMARAL, 2001, p. 16). É através, sobretudo, das investidas nesta última instância ideológica que a imprensa desempenha melhor a sua função política, fazendo da opinião, a sua vertente mais forte, pois, conforme defende Melo (2003), além do informativo, há um gênero predominante na esfera jornalística que é o opinativo. Trata-se de um 'gênero argumentativo', que emergiu no século XVIII, junto com os "processos revolucionários de natureza anti-colonial, (USA, 1776) e anti-

\footnotetext{
${ }^{7} \mathrm{O}$ desenvolvimento da caricatura política deve-se em grande parte ao período de instabilidade política na França no sec. XIX e que passou a fornecer um vasto material para os caricaturistas (FONSECA, 1999, p. 68).
} 
absolutista (França, 1789), convertendo a imprensa em arena de combate" (MELO, 2003, p. 43).

E essa força do jornalismo opinativo combativo se vê de maneira clara ao se analisar o uso das ilustrações satírico-humorísticas, as quais fazem da opinião associada ao humor, uma arma de forte potencial político-ideológico. Algo que se reflete fortemente não apenas por meio da charge, mas também através das tiras de humor, apontado como o primeiro gênero dos quadrinhos na imprensa e o mais próximo da charge, definidas por Magalhães (2006, p. 20) como "uma gag, uma piada que pode ser ingênua ou crítica, aproximando-se do teor do cartum e da charge". Por esta razão, para além dos desenhos chargísticos que são mais explicitamente políticos, conforme adverte um dos maiores pesquisadores do tema no Brasil, Moacy Cirne, a leitura dos quadrinhos exige do crítico, um sólido conhecimento dos mais diversos problemas sociais, culturais e artísticos (CIRNE, 1970, p. 14). É o que este trabalho tenta fazer ver, através do tópico a seguir, por meio da abordagem específica sobre a charge e os quadrinhos em uso na imprensa paraibana durante os anos 70, destacadamente os dois principais gêneros de ilustrações satírico-humorísticos até os dias de hoje usualmente na imprensa.

\section{AS ILUSTRAÇÕES SATÍRICAS NA IMPRENSA PARAIBANA}

Apesar de presente desde o início do século XX, são raros os registros acerca do surgimento e progresso da caricatura na Paraíba. Em seu artigo escrito sobre a história das artes visuais no estado, no início do século XX, Dyógenes Chaves faz uma pequena alusão a arte caricatural ao dizer que dentre outras categorias, a caricatura teve grande aceitação na Paraíba e noutros estados, destacando, porém que “[...] a importância social desse movimento artístico que tinha à frente jornalistas e trabalhadores da imprensa, ainda necessita de um estudo à parte para avaliar a sua significação" (CHAVES, 2013, s/n). No tocante a segunda metade do século $\mathrm{XX}$, entretanto, existem alguns registros que ajudam a traçar, se não por completo, ao menos, uma parte do percurso que caracterizou a produção e emprego das ilustrações satírico-humorísticas no contexto da imprensa paraibana. E, neste sentido, a década de 1970 se destaca como o período mais efervescente, marcado por um amplo apelo ao uso de expressões característicos do campo da caricatura, a exemplo da charge e dos 
quadrinhos que passaram a ocupar espaços fixos nas páginas de todos os principais periódicos em circulação naquele período.

Tal fenômeno se caracterizou, sobretudo, pelo engajamento político-ideológico de artistas gráficos que, a exemplo do que era feito com outros colegas no restante do país, satirizavam costumes e contestavam o poder hegemônico atacando, sobretudo, o regime militar, por meio de desenhos humorísticos debochados. Alinhados à política editorial dos periódicos para os quais trabalhavam, os desenhistas passaram a atuar na qualidade de chargistas e, posteriormente na de quadrinistas, utilizando-se dos dois gêneros como valiosos recursos ideológicos combativos. Para além da imprensa tradicional, como se verá mais adiante, os humoristas gráficos ampliaram o seu poder de ataque através da militância na imprensa alternativa onde desfrutavam de uma maior liberdade de expressão. A medida que a indústria jornalística avançava, deixando pra trás os modos mais rústicos de impressão gráfica, aprimorando, consequentemente a reprodução de imagens em suas páginas, maior era o avanço do uso das modalidades caricaturais que, de maneira lenta e gradual, foram ocupando um espaço maior nas empresas jornalísticas de pequeno e médio porte, espalhadas no interior do país ${ }^{8}$.

Em se tratando do cenário paraibano, a caricatura ganhou força e vigor a partir diante do trabalho de nomes como os de Deodato Borges, Luzardo Alves, Tônio \& Tenório, Assis Vale, Emir Ribeiro, Cristovam Tadeu, Régis Soares e Henrique Magalhães, artistas gráficos paraibanos que ajudaram a traçar a história do humor gráfico na Paraíba ${ }^{9}$. Diante do escasso espaço de trabalho profissional, muitos deles passaram a desenvolver funções diversificadas no campo da indústria de informação e entretenimento local e regional e, aos poucos, foram moldando graficamente o humor crítico paraibano. Neste contexto, o exemplo maior desse fenômeno é, sem sombra de dúvidas, o de Deodato Borges que, além de um dos pioneiros na produção de charges publicadas na imprensa, é apontado como o primeiro quadrinista paraibano.

É de autoria dele, a primeira charge (ver figura 1) publicada na imprensa campinense, conforme destaca Macedo (2012), a qual foi publicada no Jornal Diário da Borborema, o DB,

\footnotetext{
${ }^{8}$ Vale ressaltar que em se tratando da imprensa paraibana, um dos maiores progressos ocorreu a partir da implantação do sistema off-set, em meados dos anos 1970, deixando pra trás, a tipografia feita a 'chapa fria'.

${ }^{9}$ A trajetória da carreira profissional de boa parte desses artistas gráficos encontra-se registrada de forma sucinta na revista Quadrinhos da Paraíba- 30 anos de história, publicada pelo Jornal A União, Governo do Estado da Paraíba em 1993.
} 
em $1958^{10}$. A imagem fazia alusão ao título conquistado pelo Brasil na Copa Mundial de Futebol, no ano de 1958, satirizando a derrota dos times europeus no campeonato. Vale ressaltar que, na época, a publicação de charges nos jornais era feita de forma esporádica. E foi só a partir de 1962 que Deodato passou a produzir e publicar no $D B$, charges diárias retratando nelas, temas sobre temas política, futebol, comunismo e outros diversos, conforme a linha editorial do jornal (MACEDO, 2012, p. 44) ${ }^{11}$. Além deste jornal, ele chegou a produzir charges para outros jornais no Estado e fora dele. Contudo, foi a partir da criação da trama de aventura em quadrinhos As Aventuras do Flama (ver figura 2), inicialmente como um programa de rádio em 1963, e transposto neste mesmo ano o formato de revista em quadrinhos, que ele se consagrou.

Considerada a primeira revista do gênero do Nordeste naquela época, com o lançamento de um dos primeiros super-heróis brasileiros ${ }^{12}$, a publicação inaugurava o movimento das histórias em quadrinhos na Paraíba (PONTES, 1993). E, para além disto, revelava não apenas o grande talento e perfil multifuncional do artista, mas também a sua grande contribuição para a caricatura enquanto campo que abarca os mais diversos gêneros de narrativas gráficas, dentre as quais essas duas aqui destacadas. Nesse sentido, é importante destacar que ao assumir, em 1973, a função de editor de cultura do jornal O Norte ${ }^{13}$, Deodato ofertou uma grande contribuição para o avanço dos quadrinhos na imprensa estadual, ao abrir espaço para a publicação de tiras em quadrinhos, dando chances, desta maneira, para os desenhistas que trabalhavam com este gênero específico.

\footnotetext{
${ }^{10}$ Fundado em 1957 por Assis Chateaubriand, o Diário da Borborema, ou DB, como era mais conhecido, integrava o grupo empresarial dos Diários Associados e foi um dos primeiros e mais influentes jornais diários em circulação no Estado da Paraíba, com sede na cidade de Campina Grande. De acordo com Araújo (1985), tratava-se de um jornal relativamente combativo, devido seus condicionamentos políticos. O jornal fechou em 2012.

${ }^{11}$ Vale ressaltar que a função desempenhada oficialmente por Deodato Borges no jornal era a de diretor artístico e no mesmo período, também atuava como radialista na Rádio Borborema.

${ }^{12}$ As Aventuras do Flama foram inspiradas em sucessos da época, como Jerônimo, o Herói do Sertão, de Moysés Weltman e The Spirit, de Will Einer, que como era comum acontecer com programas de aventuras radiofônicos, tornaram-se histórias em quadrinhos.

${ }^{13}$ Fundado em 7 de maio de 1908, o jornal O Norte foi um dos primeiros e mais antigos jornais diários em circulação no Estado da Paraíba. Passou a pertencer ao império dos Diários Associados, de Assis Chateaubriand, em 1954. Permaneceu em circulação por mais de um século, encerrando suas atividades em fevereiro de 2012.
} 
Figura 1 - A primeira charge de Deodato Borges, publicada no DB, em 1958

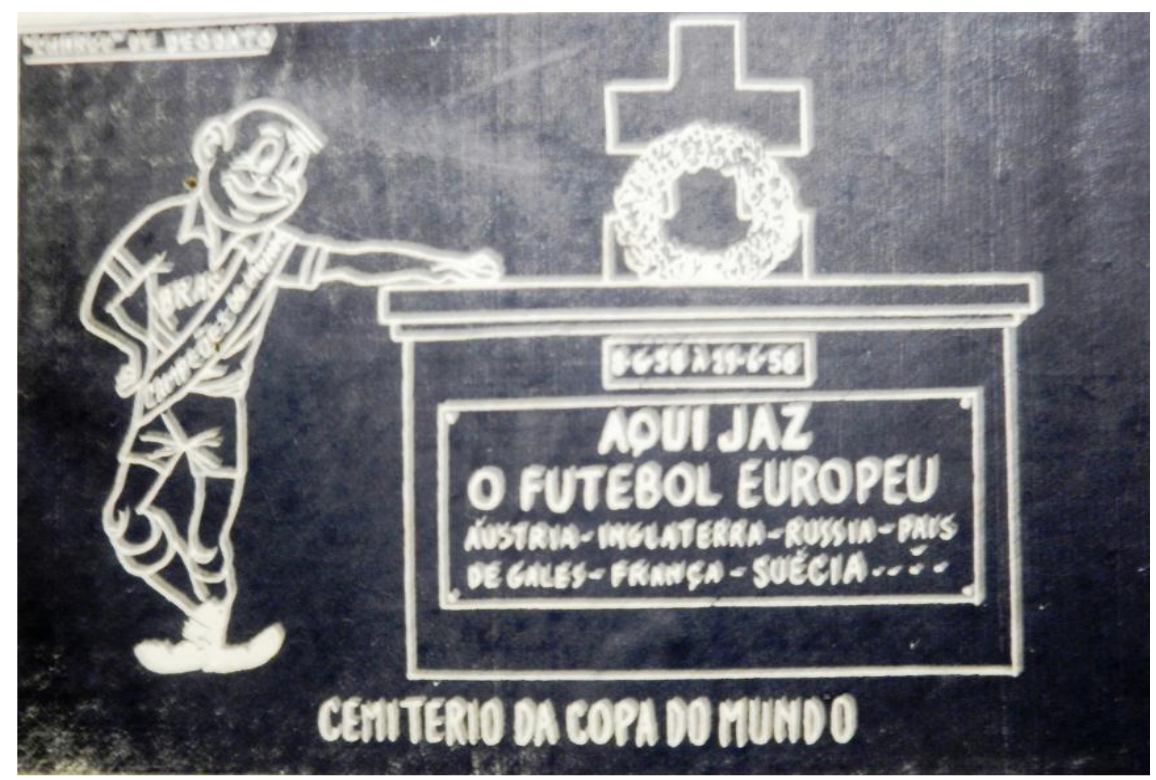

Fonte: Jornal Diário da Borborema (DB), edição de 03 de julho de 1958.

Figura 2 - Capa do primeiro número da Revista As Aventuras do Flama, 1963

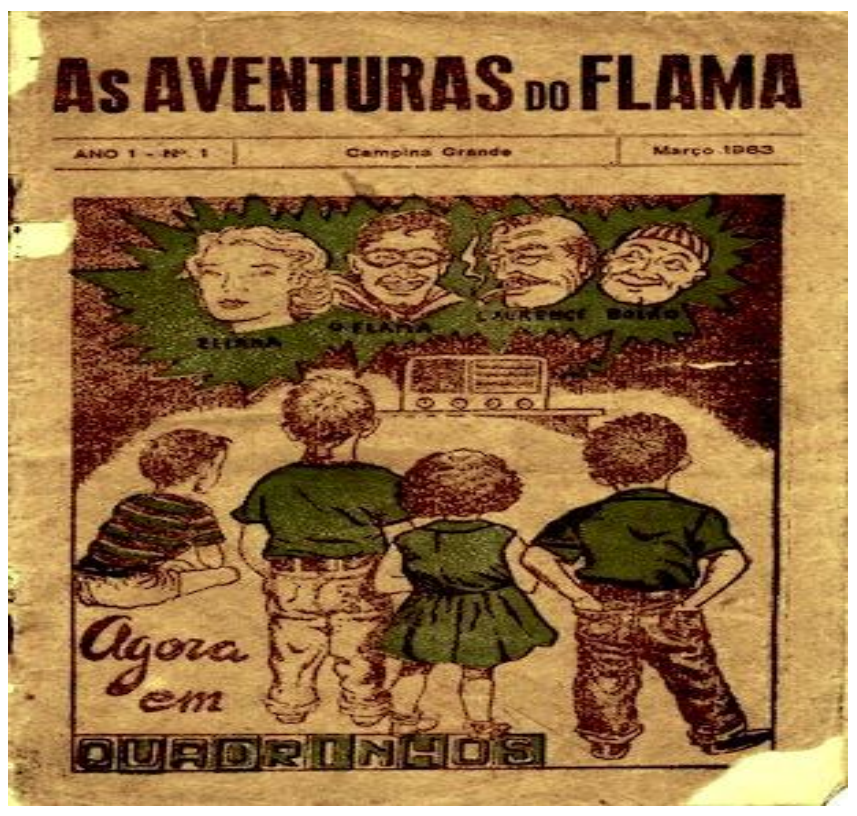

Fonte: Memorial da História em Quadrinhos da Paraíba. (http://www.memorialhqpb.org/autores/luzardoalves/luzardoalves.html)

Para além do trabalho de Deodato Borges, a trajetória da caricatura na Paraíba foi marcada significativamente através dos traços marcantes do humorista gráfico Luzardo Alves. Do mesmo modo que o conterrâneo, Luzardo atuava na década de 1960 em jornais e em emissora de rádio em funções diversas, destacando-se inicialmente na produção de cartuns, 
gênero caricatural definido, de modo simples, como desenho que traz uma crítica de costumes genérico e atemporal (ROMUALDO, 2000). Em seguida, valendo-se dos traços caricaturais, passou a produzir charges para diversas publicações, inclusive para a revista semanal ilustrada de grande circulação nacional na época, $O$ Cruzeiro, em que se divida entre as funções de cartunista e chargista ${ }^{14}$. De volta à Paraíba nos anos 1970, ele passou a produzir para publicações alternativas, dentre elas, o jornal Edição Extra, um dos mais expressivos meios satírico-humorísticos da imprensa alternativa paraibana, e que realçou a tendência da produção caricatural para a charge e os quadrinhos, conforme se verá no próximo tópico.

\section{A EXPANSÃO DA CARICATURA NOS JORNAIS PARAIBANOS}

Legitimadas pela adesão dos grandes jornais em circulação no estado nos anos 1970, as ilustrações satírico-humorísticas foram aos poucos alcançando um público de leitores consolidado conquistando consequentemente, novos espaços para sua difusão. E isto, se deu, em grande parte, devido a abertura da imprensa paraibana aos quadrinistas, sobretudo, com a criação de suplementos semanais, tais como $O$ Norte em Quadrinhos, do jornal $O$ Norte, e $O$ Pirralho, do jornal A União, os quais possibilitaram o surgimento de vários autores e o desenvolvimento de algumas dezenas de personagens. De acordo com Magalhães (2005), até então, os quadrinhos na Paraíba eram considerados apenas como um objeto de consumo e cultura de massa determinada pelos grandes editores do Sudeste. A partir da criação e publicação dos personagens fixos das tiras de histórias em quadrinhos, este gênero caricatural passou a reforçar o poder de penetração do humor gráfico na sociedade paraibana, repetindo um fenômeno que já acontecia em outros estados do país e que corroborava com o avanço dos quadrinhos na indústria de comunicação de massa.

Entre as personagens surgidas neste período e que alcançou um bom público de leitores está Maria (ver figura 3), de autoria do desenhista, quadrinista, roteirista e pesquisador acadêmico, Henrique Magalhães. Advinda no bojo da cultura alternativa, Maria surgiu em 1975 e inseriu-se em alguns dos maiores jornais comerciais do Estado, além do

\footnotetext{
${ }^{14}$ Luzardo foi contratado por Assis Chateaubriand em 1963 e foi para o Rio fazer parte do grupo de humoristas que trabalhavam para a revista. Além dos cartuns e charges, Luzardo Alves também contribuiu com o desenho de $O$ Amigo da Onça, um dos maiores do humor gráfico brasileiro que circulava na revista $O$ Cruzeiro desde os anos 1940, de autoria do humorista pernambucano Péricles de Andrade Maranhão. Com a sua morte em 1963, o personagem passou a ser desenhado por outros humoristas gráficos, dentre eles, Luzardo, conforme relatou ele em entrevista concedida ao pesquisador Henrique Magalhaes. Para mais ver Magalhaes (2016).
} 
estatal A União, e através de centenas de tiras publicadas na imprensa, manifestava a sua visão crítica acerca dos temas políticos e culturais eminentes da época, tais como a luta pela liberdade de expressão e o feminismo. E, desta maneira, aos poucos, foram surgindo várias outras personagens fictícias que se revezavam entre os quadrinhos e as charges, satirizando os costumes e a política. Dentre estes, um que se tornou bastante conhecido dos leitores paraibanos foi Pataconho, de autoria de Luzardo Alves (ver figura 4). Seguindo a linha do humor cáustico de $O$ Amigo da Onça, de quem o seu criador também se tornou desenhista, nos anos 1960, Pataconho oscilava entre a malandragem carioca e a seriedade do paulista, despertando o lado crítico do leitor. O personagem era publicado num folheto semanal intitulado Charges da Semana, publicado pelo comércio local.

Contudo, foi no espaço da imprensa alternativa que a produção caricatural se fez mais forte e politico-ideologicamente, mais combativa. Para além dos jornais que integravam a grande mídia estadual e iniciativas como as dos folhetos patrocinados por grupos sociais específicos, a arte caricatural continuou avançando durante os anos 70, consolidando o lugar da charge e dos quadrinhos no cenário estadual. Trata-se do período de maior efervescência da produção gráfico-humorística paraibana e que tinha no Pasquim ${ }^{15}$, o mais bem sucedido modelo de imprensa alternativa do país, a inspiração para os humoristas gráficos paraibanos e do restante do país. Foi desta maneira que nasceu a imprensa satírica paraibana, a qual teve no surgimento do jornal Edição Extra, um de seus marcos iniciais. Inspirados na linguagem e estilo inovador de $O$ Pasquim, os caricaturistas e jornalistas já atuantes no estado, passaram a investir na proposta satírica e combativa propagada pelo semanário ilustrado que, vale dizer, contou com a participação de alguns caricaturistas paraibanos, dentre eles Regis Soares e Fred Ozanan ${ }^{16}$.

\footnotetext{
${ }^{15}$ O Pasquim foi editado entre junho de 1969 a novembro de 1991 e reuniu os maiores nomes da caricatura brasileira, a exemplo de Ziraldo, Jaguar, Henfil, Milor Fernandes e, de acordo com Melo (2003, p. 171) representou uma síntese do jornalismo caricato em que" traço e texto, lado a lado, ironizam o cotidiano e satirizam os protagonistas da notícia [...]". O Pasquim atingiu a marca de mais de 200 mil em seu auge, em meados dos anos 1970, se tornando um dos maiores fenômenos do mercado editorial brasileiro.

${ }^{16}$ Trata-se de dois dos maiores chargistas paraibanos que atuaram em diversos órgãos da imprensa estadual e fora do Estado, cujo trabalho já foi alvo de pesquisas acadêmicas diversos. Regis Soares é conhecido em toda a João Pessoa através do projeto Charge na Rua, que expõe através de painéis colocados na calçada da rua em que reside, charges políticas e sociais. Fred Ozanan é chargista, caricaturista e cartunista que passou a atuar a partir dos anos 1980, detentor de vários prêmios em salões de humor e autor de vários livros sobre humor gráfico. Para saber mais, ver Brito (2002).
} 
Figura 3 - As personagens de HQ's paraibanos: Pataconho e Bat-Madame
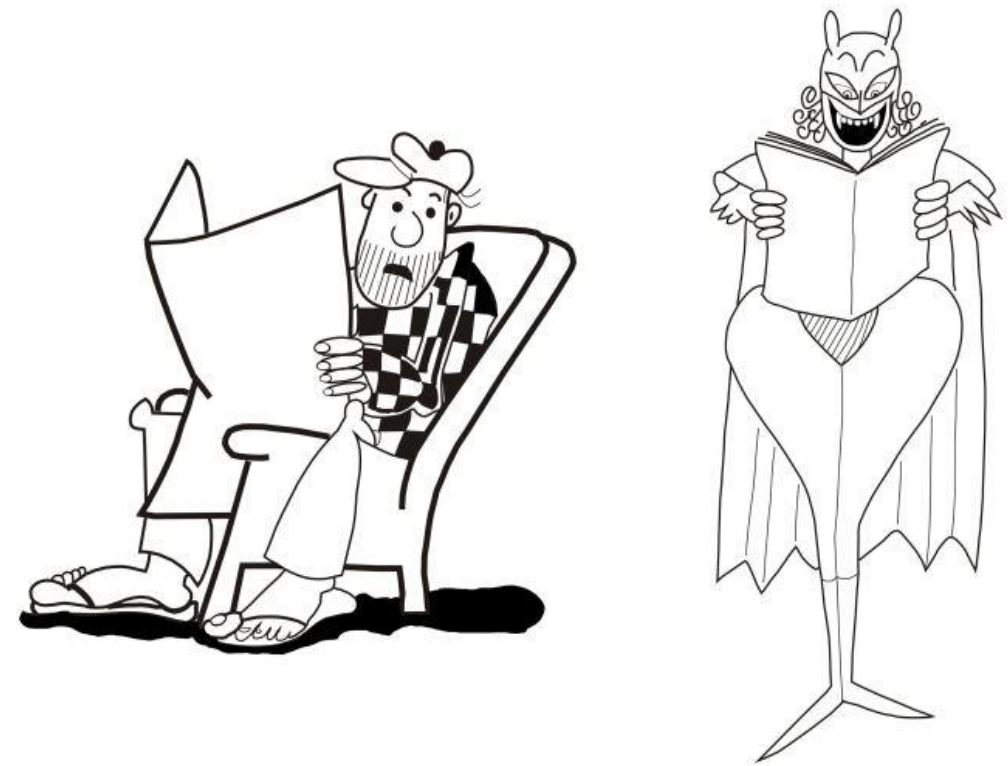

Fonte: blog Memorial HQ Paraibana

(http://www.memorialhqpb.org/autores/luzardoalves/luzardoalves.html)

Figura 4 - Tira com a personagem Maria, de autoria de Henrique Magalhães
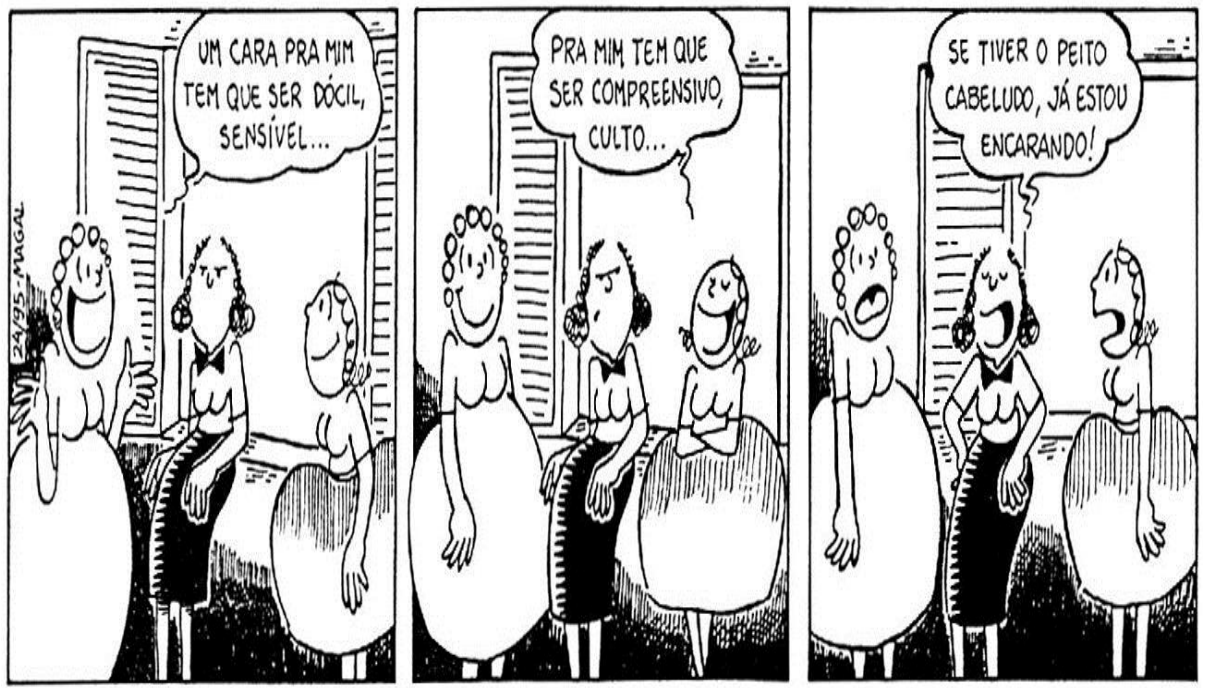

Fonte: Memorial da História em Quadrinhos da Paraíba (http://www.memorialhqpb.org/autores/luzardoalves/luzardoalves.html)

O Edição Extra foi criado por um grupo de profissionais da imprensa em 1971 e apresentava uma proposta política e ideológica centrada em denúncias sérias em tom humorístico, não chegando, por isto, ser muito percebido pelos censores (ALVES, 2016). O jornal trazia quatro editorias: política, cidade, humor e de arte. Essas duas últimas ficaram sob a responsabilidade de Anco Márcio e Luzardo Alves que juntos, para além do trabalho 
chargístico, criaram uma das mais irônicas personagens e famosas dos quadrinhos paraibanos: Bat-Madame (ver figura 4). A personagem trazia uma sátira escrachada de Batman e dos costumes da região (ALVES, 2016, p. 06). Mesmo com vida curta (agosto a outubro de 1971), o periódico reforçou a tendência da Paraíba para a caricatura e o movimento jornalístico alternativo.

O fato de o jornal ser alternativo, numa estrutura em que só existiam as grandes empresas, já lhe dava uma importância fora do comum. Inspirado em $O$ Pasquim, maior renovador da imprensa brasileira na segunda metade do século XX, Edição Extra assimilava muito bem o senso crítico e humorístico desse semanário carioca, focalizando os acontecimentos políticos e sociais do estado (ALVES, 2016, p. 26).

Tais características foram ainda mais acentuadas, oito anos depois, com a chegada do jornal $O$ Furo $^{17}$. O periódico nasce a partir da iniciativa de um grupo de jovens estudantes paraibanos inconformados com o clima de censura reinante em todo o país naquela época e engajados na luta contra a forte repressão instituída pelo golpe civil-militar implantado no Brasil desde 1964. A publicação conseguia misturar jornalismo de conteúdo sério com uma certa dose de irreverencia, mesclando tiras e charges com entrevistas de cunho extremamente político (ALMEIDA, 2010, p. 02). Entre os seus idealizadores estava o chargista Richard Muniz que, assim como a maioria dos demais humoristas gráficos conterrâneos seus, atuou na imprensa tradicional e nos periódicos alternativos e de forma biunívoca, manifestou nas charges e nos quadrinhos, os traços caricaturais carregados de ideologia contestatória.

A vida e morte do jornal $O$ Furo coincide com o período apontado como o fim do ciclo da imprensa alternativa brasileira quando, conforme descreve Kucinski (2001, p. 94), "como se tivesse ocorrido um cataclisma, quase todos os jornais alternativos que circulavam entre 1977 e 1979 deixaram de existir”. Não obstante, a produção satírico-humorística prossegue, porém, migrando cada vez mais para as páginas dos jornais e revistas da grande imprensa seja em nível nacional ou estadual que passam a inserir, para dentro de seus quadros profissionais, os humoristas gráficos e sua vertente de humor satírico. Paralelo a esta realidade, muitos desenhistas investiram no mercado editorial de produção independente, incrementando ainda mais o cenário profissional que, apesar das sucessivas e grandes crises

\footnotetext{
${ }^{17}$ Embora a abertura política tenha se dado em 1982, alguns anos antes a imprensa já tinha conquistado, aos poucos e a duras penas, uma discreta liberdade de expressão. Apesar dessas evoluções, voltadas para a redemocratização do país, o Brasil estava longe de ser livre e muitos dos direitos dos cidadãos não eram efetivamente respeitados. Foi nessa conjuntura favorável que surgiu o Furo que possuía tiragem quinzenal com cerca de 3 mil exemplares, com 24 páginas cada uma delas (ALMEIDA 2010).
} 
econômicas que marcaram os anos 80 e 90, conseguiram dinamizar o campo da arte gráfica caricatural. Dentre as iniciativas bem sucedidas, está o retorno do personagem Maria, de Henrique Magalhães que, de todos os que surgiram na década de 1970, foi o de maior duração, permanecendo até os dias de hoje viva graças ao mercado editorial gráfico independente.

\section{CONSIDERAÇÕES FINAIS}

Muito mais que recurso meramente ilustrativo, ninguém pode negar a importância do desenho humorístico na imprensa, seja como valioso instrumento para fazer rir e ao mesmo tempo refletir, seja como documento histórico e fonte de infinita capacidade de representação social, política e cultural de diferentes épocas da humanidade. As ilustrações satíricohumorísticas que compõem o vasto e diversificado campo da caricatura atestam essa realidade. $\mathrm{O}$ breve panorama traçado pela charge e os quadrinhos na imprensa paraibana durante os anos 70, aqui apresentado, ajuda a confirmar essa afirmativa. Mais que isso, o recorte descrito nos fornece uma visão mais clara acerca de como esses dois gêneros encontram-se próximos, um do outro, e sobre como eles tem auxiliado no processo de evolução do humor gráfico no universo jornalístico e, para além deste.

O registro apresentado reforça o lugar de destaque destes gêneros aqui destacados no percurso de desenvolvimento da caricatura no contexto da imprensa paraibana, chamando a atenção para os aspectos gráfico-narrativos e político-ideológicos que não apenas aproximam, um do outro, mas também nos fazem compreender melhor a função política desempenhada pelo humor gráfico no âmbito do universo jornalístico. Trata-se aqui de dois elementos cujo desenvolvimento confunde-se, de certa forma, com a própria história de progresso e transformação da imprensa, como se pôde ver. Ao analisar a contribuição de alguns dos principais humoristas gráficos paraibanos que surgiram ao longo do período recortado, ficou evidente não apenas a imbricação da charge com o gênero específico dos quadrinhos que são as tiras cômicas, mas também a maneira sutil e transitória com que muitos dos humoristas gráficos trafegam entre esses dois gêneros caricaturais, contribuindo com a valoração e consolidação das ilustrações satírico-humorística enquanto valiosos objetos de estudo para os historiadores que, em detrimento dos trabalhos já publicados até aqui, ainda precisam 
mergulhar mais fundo no universo da iconografia, explorando de maneira ainda mais profícua, o potencial dos documentos históricos de que esta se faz portadora.

Por fim, em consonância com outras publicações já apresentadas sobre a historiografia da caricatura, ainda que de forma breve, este trabalho parece evidenciar o quanto a produção satírico-humorística registra com humor e criticidade, não apenas os nuances políticos, sociais e culturais que transformam as sociedades, mas também àquelas que mudam a própria forma da imprensa registrar tais nuances. Algo visto de maneira nítida ao se observar aquilo que diferencia a imprensa tradicional da imprensa alternativa e o modo como cada uma dessas se utilizou do humor gráfico, no transcorrer do período aqui apresentado e que espelha um fenômeno que, guardando as devidas proporções conjunturais, se repetiu no restante do país. O breve panorama do contexto da imprensa paraibana aqui apresentado serve como parâmetro para tal observação. Neste sentido, este trabalho esperar somar-se às contribuições que a pesquisa histórica pode oferecer dentro da vasta e inconclusa historiografia sobre o desenvolvimento da imprensa como um todo e da qual, a paraibana, é um capítulo inclusa e a espera de novas investigações históricas.

\section{REFERÊNCIAS BIBLIOGRÁFICAS}

ALVES, Luzardo. O humor gráfico de Luzardo Alves. Paraíba: Marca de Fantasia, 2016.

ALMEIDA, Marina. A voz alternativa da imprensa paraibana: a breve história de um jornal alternativo. $2010.20 \mathrm{em}$ <http://www.insite.pro.br/2010/Mar\%C3\%A7o/Reportagem\%20O\%20Furo\%20Marina\%20A lmeida.pdf > . Acesso em: 23. Jul.2017.

AMARAL, Luíz. Técnica de Jornal e Periódico. Rio de Janeiro: Tempo Brasileiro; Biblioteca Tempo Universitário, 2001.

ARAÚJO, Fátima. Paraíba: imprensa e vida. Campina Grande: Grafset, 1985.

BAHIA, Juarez. Jornal, história e técnica: história da imprensa brasileira. $4^{\mathrm{a}}$ ed. São Paulo: Ática, 1990.

BARBIERI, Daniele. As linguagens dos quadrinhos. São Paulo: Peirópolis, 2017

BRITO, Rosildo. A opinião no riso: uma análise da intertextualidade na construção da significação de charges na imprensa paraibana. Dissertação (Mestrado Interdisciplinar em Ciêncais da Sociedade). Campina Grande: Universidade Estadual da Paraíba - UEPC, 2002.

CAVALCANTI, Lailson de Holanda. Historia del Humor Gráfico en el Brasil. Lleida, Editorial Milenio, 2005. 
CIRNE, Moacy. A explosão criativa dos quadrinhos. Petrópolis: Vozes, 1970.

CHAVES, Dyógenes. Artes visuais na Paraíba: 1900-2010. Arte \& Crítica- Jornal da ABCA. 2013. Disponível em: <http://abca.art.br/n27/13artigos-dyogenes.html>. Acesso em 12 set 2017.

FONSECA, Joaquim da. Caricatura. A imagem gráfica do humor. Porto Alegre: Artes e Ofícios, 1999.

GAWRYSZEWSKY, Alberto. Conceito de caricatura: não tem graça nenhuma. Domínios da imagem. Londrina. Maio 2008.2 Disponível em <http://www.uel.br/revistas/uel/index.php/dominiosdaimagem/article/view/19302〉. Acesso em: 12. Nov 2017.

LIMA, Herman. Historia da Caricatura no Brasil. Rio de Janeiro: José Olympio, 1963.

MACEDO, José Emerson Tavares de. A linguagem humorística das charges e as "Diretas já ": no traço dos chargistas dos jornais: Diário da Borborema e Jornal da Paraíba. Dissertação (Mestrado em História), Universidade Federal de Campina Grande - UFCG, 2012.

MAGALHÃES, Henrique. Humor em pílulas: a força criativa das tiras brasileiras. Joao Pessoa:Marca de Fantasia, 2006.

. Maria: espirituosa, há 30 anos. Joao Pessoa:Marca de Fantasia, 2005.

MAGNO, Luciano. História da caricatura brasileira. Gala Edições de Arte, Rio de Janeiro, 2012.

MELO, José Marques de. Jornalismo opinativo: gêneros opinativos no jornalismo brasileiro. São Paulo: Mantiqueira, 2003.

MENESES, Ulpiano Toledo Bezerra de. Fontes Visuais, Cultura Visual, História Visual: balanço provisório, propostas cautelares. In: Revista Brasileira de História. Volume 23, número 45. São Paulo: ANPUH, 2003. Pp. 11-36. Disponível em <www.scielo.br.> Acesso em 12 jan 2017.

PONTES, Juca. Quadrinhos da Paraíba: 30 ANOS. Editora: Jornal A União, 1993.

RAMOS, Paulo. A leitura dos quadrinhos - coleção Linguagem \& Ensino. São Paulo: Ed. Contexto, 2009.

RIANI, Camilo. Tá rindo do quê? (Um mergulho nos salões de humor de Piracicaba). Piracicaba: UNIMEP, 2002.

ROMUALDO, Carlos Edson. Charge jornalística: intertextualidade e polifonia. Maringá:Eduem, 2000.

SODRÉ, Nelson Werneck. História da imprensa no Brasil. Rio de Janeiro: Mauad, 1999. 
Fronteiras: Revista de História

Humor politizado: o uso das ilustrações satíricas na imprensa paraibana nos anos 70

Rosildo Raimundo Brito

VERGUEIRO, Waldomiro. Panorama das histórias em quadrinhos no Brasil. São Paulo: Petrópolis, 2017.

VOVELLE, Michel. Imagens e imaginário na História. São Paulo: Ática, 1997.

Recebido em: 29/05/2018

Aprovado em 30/07/2018

Fronteiras: Revista de História | Dourados, MS | v. 20 | n. 35 | p. 137 - 153 | Jan. / Jun. 2018 